\title{
Callus induction in Bertholletia excelsa immature seeds
}

\author{
Maurício Reginaldo Alves dos Santos ${ }^{1, *}$, Maria das Graças Rodrigues Ferreira ${ }^{2}$, Sandra \\ Mirlêny da Silva Carvalho ${ }^{3}$
}

\begin{abstract}
Bertholletia excelsa H.B.K., known as Brazil nut tree, belongs to the Lecythidaceae botanic family and is endemic to the Amazonian Region. Its nuts have high economic and nutritional value. The objective of this work was to establish efficient protocols for callus induction from immature seeds of B. excelsa, as a preliminary step to its further micropropagation. After disinfestation, fragments of immature seeds were cultivated in WPM (Wood Plant Medium) supplemented with 2,4-D $\left(0,1,2,4\right.$ and $\left.8 \mathrm{mg} . \mathrm{L}^{-1}\right)$ and TDZ $\left(0,1.6\right.$ and $\left.3.2 \mathrm{mg} . \mathrm{L}^{-1}\right)$ in factorial combination. Twenty-one days later the callus induction was evaluated. Cultures were kept in a growth room in the dark at $24 \pm 2^{\circ} \mathrm{C}$. The highest percentage of callus induction was found with the combination of 2 mg. $L^{-1} 2,4-D$ with $3.2 \mathrm{mg} . \mathrm{L}^{-1} \mathrm{TDZ}$.
\end{abstract}

Keywords: callus induction, growth regulators, Amazon Rainforest.

\section{Indução de calos em sementes imaturas de Bertholletia excelsa}

\section{RESUMO}

Bertholletia excelsa H.B.K., conhecida como castanheira-do-brasil, pertence à família Lecythidaceae e é uma espécie endêmica da Amazônia. Suas castanhas têm importante valor econômico e nutricional. Objetivou-se com esse trabalho determinar um protocolo eficiente para indução de calos em explantes de sementes imaturas de B. excelsa, primeiro passo para o estabelecimento de um protocolo de micropropagação da espécie. Após desinfestação, fragmentos de sementes imaturas foram cultivados em meio WPM (Wood Plant Medium) acrescido de 2,4-D (0, 1, 2, 4 e 8 mg. $\left.\mathrm{L}^{-1}\right)$ e TDZ $\left(0,1,6\right.$ e 3,2 mg.L $\left.\mathrm{L}^{-1}\right)$ em combinação fatorial. Após 21 dias, foi avaliada a indução de calos. Os cultivos foram mantidos no escuro, em sala de crescimento, a $24 \pm 2^{\circ} \mathrm{C}$. A condição que resulta em maior porcentagem de calogênese foi encontrada na combinação de $2 \mathrm{mg} . \mathrm{L}^{-1}$ de 2,4-D com 3,2 mg. $\mathrm{L}^{-1}$ de TDZ. Palavras chave: Indução de calos, reguladores de crescimento, Floresta Amazônica.

\footnotetext{
*Autor para correspondência.

${ }^{1}$ Doutor em Agronomia; Embrapa Rondônia; CP 127, 76815-800, Porto Velho-RO, Brasil. mauricio.santos@embrapa.br

${ }^{2}$ Doutora em Agronomia; Embrapa Cocais; Av. São Luís Rei de França, nº, 65065-470, São Luís-MA, Brasil.

${ }^{3}$ Mestre em Desenvolvimento Regional e Meio Ambiente; Universidade Federal de Rondônia -UNIR; BR 364, km 9,5, 76801-059, Porto Velho-RO, Brasil.
} 


\section{INTRODUCTION}

Bertholletia excelsa H. B. K., known as Brazil nut tree, is an endemic Amazonian species in the Lecythidaceae botanic family which has great economic and social value due to its high quality wood and edible seeds (Serra et al. 2000). Its nuts have high nutritional value and is called "vegetable meat" for its remarkable content of protein, calories, fat, and minerals, with the half the protein level and twice the caloric level as a 100 grams piece of beef; the "milk" produced from the Brazil nut has approximately as much as protein as cow's milk, and can be used as a culinary replacement; there are also high concentrations of methionine, sulfuric amino acid quite limited in the Amazon diet and often found in meat and beans (Cymerys et al. 2005). It is considered one of the major sources of selenium, which is used as an antioxidant and anticarcinogenic, and helps in the prevention of some types of viruses, Parkinson's and Alzheimer's (Fillion 2011).

The trees occur naturally in clusters; the density per hectare varies and the average is around one productive tree per hectare; the production per tree can reach 2,000 fruits with 8-24 seeds each (Shanley et al. 2010,Clement 1999). Almost all harvested Brazil nut is exported and after the decline of the rubber industry the Brazil nut became the main product for export from northern Brazil in the category of commodities (Serra et al. 2000). In 1999, Brazilian production was 19,000 tons; the state of Acre was the largest producer with 10,000 tons; in 2000, production rose to 33,000 tons and generated an income of more than US\$ 18 million (Shanley et al. 2010).

In respect of the reproductive propagation, a major difficulty is the slow and uneven germination process thattakes12-18 months to occur naturally, due to endogenous seed dormancy that appears to be favorable for increasing the effective storage period of Brazil nut; during storage, embryo maturation may take place and/or a chemical inhibitor is leached from the embryos, resulting in improved germination (Kainer et al. 1999). Moreover, the seeds are recalcitrant, decreasing the ability of germination with reduction in moisture content. Because of this, a period of moist-storage over five and a half months is recommended to achieve approximately $75 \%$ germination (Kainer et al. 1999). Besides, crossed pollination generally leads to variability among progenies, what can be undesirable in terms of production (Santos et al. 2010a).
The establishment of commercial plantations depends on the use of technologies that allow the vegetative propagation of this species (Shanley et al. 2010, Müller and Freire 1979). However, in the specific case of $B$. excels the conventional vegetative propagation is achieved by grafting and this method depends on the establishment of the rootstock through seed germination and plantlet development (Locatelli and Souza 1990), which leads to the same problems of the reproductive propagation.

Plant tissue culture can contribute to overcome propagation problems. This comprises a set of techniques in which each explant (cell, tissue, or organ) is isolated and grown under aseptic conditions in artificial nutritive medium (Grattapaglia and Machado 1998). Through tissue culture it is possible to obtain virus-free plants, conservation and exchange of germplasm, interspecific and intergeneric hybridization, mutations induced by somaclonal variation, production of secondary metabolites, and others(Ferreira 2006). The plant tissue culture has enormous potential for use in many different areas, especially in plant breeding; and the most practical application of tissue culture is micropropagation, which has shown wide applications in agriculture and forestry science (Barbosa 2001).

Micropropagation has as main advantages the rapid increase in the number of individuals and the possibility of germplasm conservation, ensuring the maintenance of biodiversity and can occur through multiplication by indirect organogenesis, with a callus phase in which any plant tissue can be used as an explant for callus induction (Grattapaglia and Machado 1998). However, calluses are in general induced more easily in explants containing meristematic tissue or having a greater capacity to express totipotency and explants of young tissues, not lignified, are more appropriate to initiate a callus culture (Nogueira et al. 2007). The establishment of an appropriate protocol for callus induction with regenerative potential can help the future adoption of unconventional breeding techniques (Oliveira et al. 2007).Callus formation has been used for mass propagation of various species by the formation of multiple shoots or somatic embryogenesis, morphogenetic responses from which seedlings can be produced with good agronomic characteristics (Santos et al. 2010b). Thus, the objective of this work was to establish an efficient 
protocol for callus induction in $B$. excelsa immature seeds, since currently there is no

\section{MATERIALS AND METHODS}

\section{Plant Materials and Sterilization.}

Immature seeds were collected from healthy Bertholletia excelsa H.B.K. stock plants from the experimental field of Embrapa Rondonia, in Porto Velho, Rondônia State. At the Plant Biotechnology Laboratory the seeds were washed with running tap water and a detergent agent for five minutes. After that, in a laminar flow cabinet, the seeds were immersed in $70 \%(\mathrm{v} / \mathrm{v})$ ethanol for 1 minute and soaked in a $1 \%(\mathrm{v} / \mathrm{v})$ sodium hypochlorite solution for 10 minutes, and then rinsed three times with sterile water. Explants were produced by cutting the seeds with a scalpel into pieces of approximately $1 \mathrm{~cm}^{3}$ in sterile Petri dishes.

\section{Medium and Culture Conditions.}

Test tubes were used containing $10 \mathrm{~mL}$ of a Wood Plant Medium (Lloyd and McCown 1981) with $3 \%(\mathrm{w} / \mathrm{v})$ sucrose and $0.8 \%(\mathrm{w} / \mathrm{v})$ agar. In order to achieve the callus the medium was supplemented with 2,4-Dichlorophenoxyacetic acid (2,4-D) and

\section{RESULTS AND DISCUSSION}

Callus formation in immature seeds of $B$. excelsa occurred from the $12^{\text {th }}$ to the $15^{\text {th }}$ day after inoculation. The explants became tumid, which indicated the start of the callus induction process (Fig. 1).

According to the analysis of variance (Table 1) there was interaction between the two growth regulators. The three concentrations of TDZ did efficient system of propagation, either by grafting or by seed.

Thidiazuron (TDZ). The $\mathrm{pH}$ of the medium was adjusted to 5.8 before addition of agar followed by autoclaving at $121^{\circ} \mathrm{C}$ for 20 minutes. All the cultures were incubated in a growth chamber at 24 $\pm 2{ }^{\circ} \mathrm{C}$ under a photoperiod of 16 hours of light provided by cool white fluorescent lamps (50 mmol. $\mathrm{m}^{2} \cdot \mathrm{s}^{2}$ ).

\section{Callus Induction.}

Seed explants were individually transferred onto medium supplemented with a factorial combination of 2,4-D at the concentrations of 0,1 , 2 , 4, and $8 \mathrm{mg} . \mathrm{L}^{-1}$ and TDZ at the concentrations of $0,1.6$, and $3.2 \mathrm{mg} . \mathrm{L}^{-1}$, totaling 15 treatments.

\section{Experimental Design and Evaluation.}

The 15 treatments were arranged in a complete randomized design. There were four replications per treatment and each replication was composed by five test tubes, totaling 20 tubes per treatment and 300 explants in the whole experiment. The number of callus per explant was evaluated at the $21^{\text {st }}$ day of culture and submitted to analysis of variance and quadratic regression by using the Genes statistical program.

not differ from each other. However, the five concentrations of 2,4-D differed significantly. Thus, a comparison of these concentrations in combination with each TDZ concentration was carried out. It was possible to observe that the concentrations of 2,4-D differed significantly only when they were in combination with $3.2 \mathrm{mg} . \mathrm{L}^{-1}$ TDZ. In this way, a regression curve was established to this later situation (Fig. 2).

Table 1: Calculated $F$ values for percentages of callus induction in explants of immature seeds of $B$. excelsa in response to different concentrations of 2,4-D and TDZ in MS medium 21 days after inoculation. Porto Velho, Rondônia State, Embrapa Rondônia, 2013.

\begin{tabular}{|c|c|c|c|}
\hline Sourcesofvariation & $f$ & MS & $\mathbf{F}$ \\
\hline Between treatments & 14 & 4,20 & $7,78^{* *}$ \\
\hline Within treatments & 45 & 0,54 & \\
\hline TDZ & 2 & 0,07 & $0,12^{\mathrm{ns}}$ \\
\hline 2,4-D & 4 & 6,79 & $12,58^{* *}$ \\
\hline TDZ x 2,4-D & 8 & 3,94 & $7,30 * *$ \\
\hline 2,4-D (0 mg.L $\left.\mathrm{L}^{-1} \mathrm{TDZ}\right)$ & 4 & 0,8 & $1,48^{\mathrm{ns}}$ \\
\hline 2,4-D (1.6 mg.L $\left.\mathrm{L}^{-1} \mathrm{TDZ}\right)$ & 4 & 0,01 & $0,02^{\mathrm{ns}}$ \\
\hline 2,4-D (3.2 mg.L $\left.\mathrm{L}^{-1} \mathrm{TDZ}\right)$ & 4 & 4,05 & $7,5 * *$ \\
\hline $\mathrm{CV}(\%)$ & & 9,71 & \\
\hline
\end{tabular}

${ }^{\mathrm{ns}}$ not significant; $* *$ significant at $1 \%$ of probability. 


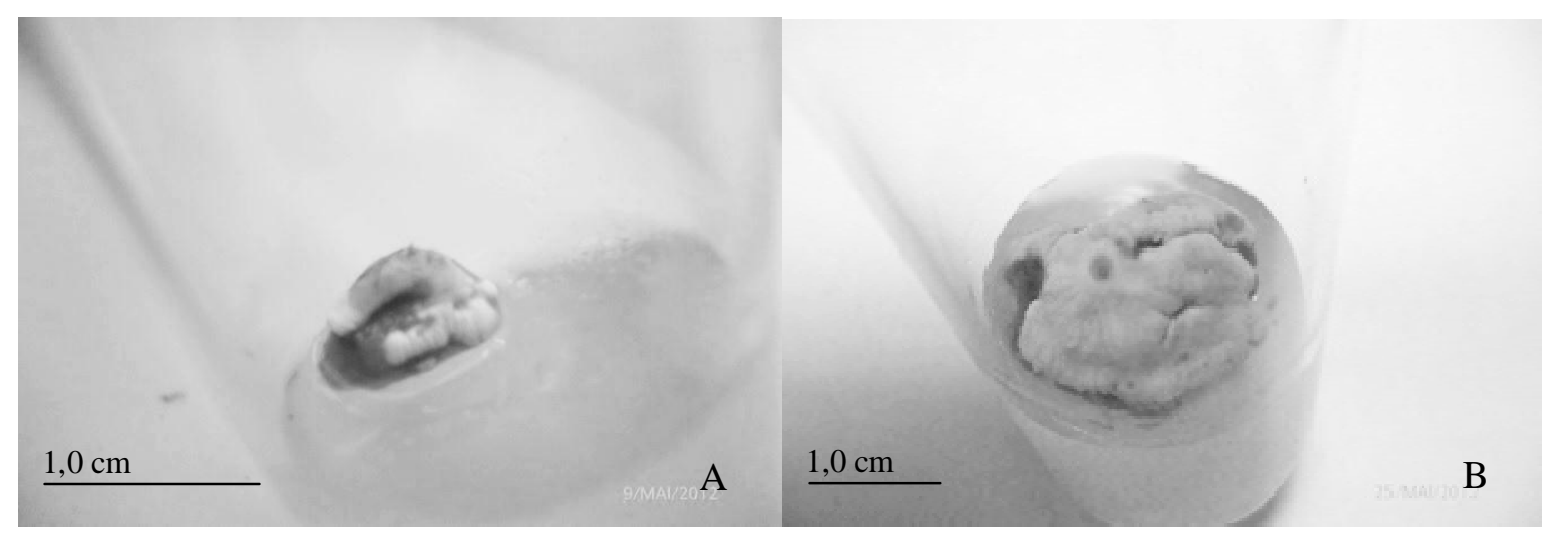

Figure 1: Response of explants of $B$. excelsa immature seeds to supplementation of $2.0 \mathrm{mg} . \mathrm{L}^{-1} 2,4-\mathrm{D}$ and $3.2 \mathrm{mg} . \mathrm{L}^{-1} \mathrm{TDZ}$ in MS medium.(A) 15 days after inoculation, in the beginning of callus induction; and (B) 21 days after inoculation, with the entire surface covered by callus structure. Porto Velho, Rondônia State, Embrapa Rondônia, 2013.

Serra et al. (2000) also observed callus formation at the $15^{\text {th }}$ day of culture in leaf explants of $B$. excelsa by supplementing the medium with 0.5 mg.L $\mathrm{L}^{-1} 2,4-\mathrm{D}$ and $2.0 \mathrm{mg} . \mathrm{L}^{-1} 6$-benzylaminopurine (BA). The authors found an exponential phase between the $30^{\text {th }}$ and the $53^{\text {rd }}$ days, when major growth occurred $(74 \%)$ and the deceleration phase between the $60^{\text {th }}$ and the $67^{\text {th }}$ days, when the minor growth occurred. The general growth of the callus is slow, probably due to a long cellular cycle.

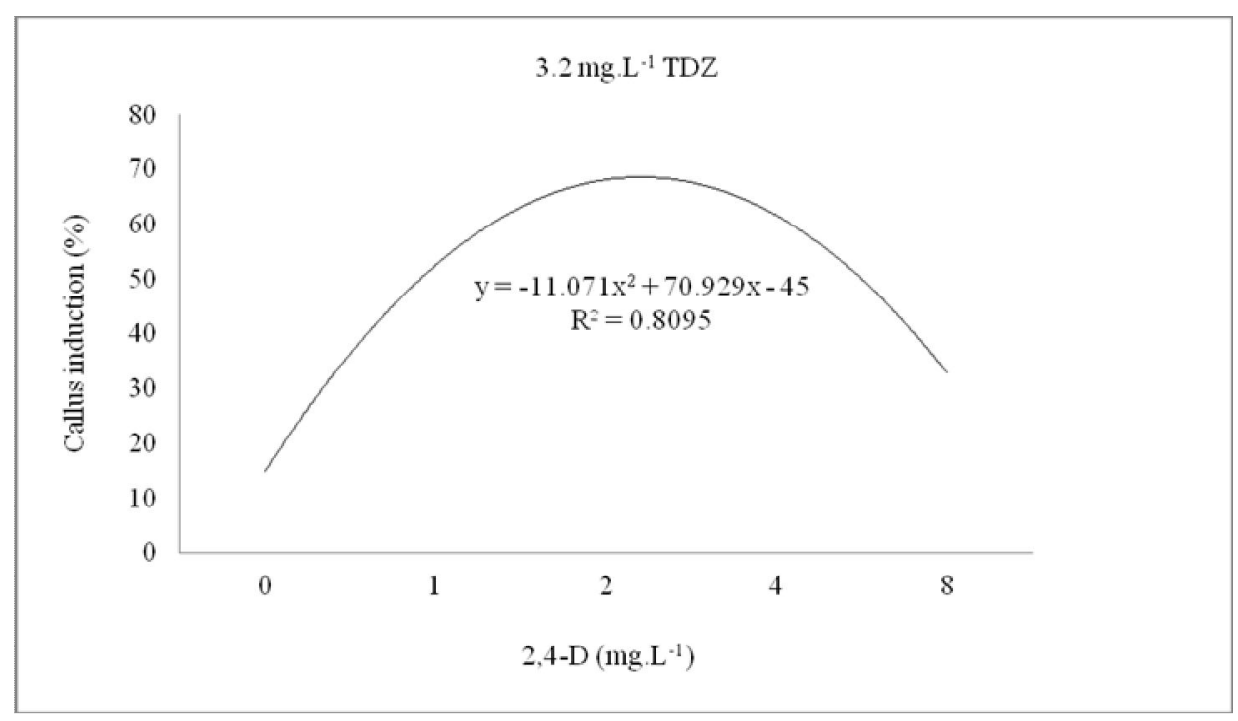

Figure 2: Regression curve of callus induction in explants of immature seeds of $B$. excelsa in response to different concentrations of 2,4-D in combination with $3.2 \mathrm{mg} \cdot \mathrm{L}^{-1} \mathrm{TDZ}$ in MS medium 21 days after inoculation. Porto Velho-RO, Embrapa Rondônia, 2013.

Little is known so far about the molecular mechanisms of auxin-cytokinin interactions. It is believed that a possible interaction could be found in the metabolism of both hormones, one hormone class could influence the activity of enzymes involved in the biosynthesis or inactivation of the other (Kerbauy 2004). 
Callus induction is dependent on a balance of auxin and cytokinin, which acts in cell cycle regulation, and probably the supply of endogenous cytokinins plus cytokinins present in the nutrient medium would result in a high cytokinin concentration in relation to auxin, causing a decrease in callus formation (Kerbauy 2004). The induction of callus in seeds of tree species in general involves a combination of cytokinins and auxins and has been studied by several authors: Khan et al. (2001) obtained $63.8 \%$ callus induction from Bixa orellana entire seeds inoculated in MS medium supplemented with $0.93 \mathrm{mg} . \mathrm{L}^{-1} \mathrm{NAA}$ and $0.56 \mathrm{mg} . \mathrm{L}^{-1}$ BA. Tang et al. (1998) achieved the maximum percentage of $35.7 \%$ callus induction from mature zygotic embryos of Pinus taeda L. by using $10.0 \mathrm{mg} . \mathrm{L}^{-1} \mathrm{NAA}$ and $4,0 \mathrm{mg} . \mathrm{L}^{-1} \mathrm{BA}$ in TE medium. Bonneau et al. (1994) also utilized mature zygotic embryos for callus induction in Euonymus europaeus L. and obtained $16.7 \%$ with $1.0 \mathrm{mg} . \mathrm{L}^{-1}$ NAA and $0.1 \mathrm{mg} . \mathrm{L}^{-1}$ BA in $\mathrm{MS}$ medium.

In the absence of both regulators there was $30 \%$ of callus induction probably due to the physical injurie to which the explants were submmited, when cut by scalpel. Callogenesis is often assossiated with presence of auxins in the medium, but is not necessarily auxin-dependent (Borges et al. 2006). During the in vitro establishment of explants growth regulators act supplementing the possible lack or low level of endogenous hormones, as the explant is isolated from the production areas of the plant (Machado et al. 2011).

Thurow et al. (2009) achieved high callus induction in leaf explants of Prunus salicina Lindl. with $1 \mathrm{mg} . \mathrm{L}^{-1}$ 2,4-D. Ferreira et al. (2007) also observed callogenesis in leaf explants of Ficus carica L. with $4 \mathrm{mg} . \mathrm{L}^{-1}$ 2,4-D. Silva et al. (2009) induced callus in anthers of Coffea arabica $\mathrm{L}$. with 2 mg. $L^{-1} 2,4-\mathrm{D}$.

Auxins are capable of iniciating cellular division and controlling growth processes and cellular elongation. 2,4-D acts in the RNA metabolism inducing the RNA messengers capable of decoding proteins involved with plant growth and disordered proliferation (Nogueira et al. 2007).

Growth regulators do not influence plant responses exclusively by changing their concentrations, as the regulation can also be exerted by changes in the sensibility of responsive cells. In this way, responses to a determined growth regulator can be altered by changes in a) the number and affinity of receptors, and b) the level of other endogenous substances (Guerra et al. 1998).

The highest callus induction corresponded to $75 \%$ of the explants and occurred with the combination of $2 \mathrm{mg} . \mathrm{L}^{-1}$ 2,4-D with $3.2 \mathrm{mg} . \mathrm{L}^{-1}$ TDZ. This cytokinin is a potent indutor of multiplication, as it can promote the biological activity of endogenous cytokinins (Ribeiro et al. 2010). The percentage of $75 \%$ is satisfatory, as the callus can grow and be multiplied several times according to its final utilization - organogenesis or embryogenesis.

Higher concentrations of 2,4-D resulted in lower levels of callogenesis, as an outcome of the phytotoxicity of this growth regulator at high concentrations. The shape of the curve observed in Figure 2 is typical for callus induction and often represents an increase on the percentage of explants with callus cells until reach a maximum; followed by a decrease that means saturation and maybe toxic effect of high concentrations. The same was obtained by Santos et al. (2012) with leaf explants of Bactris gasipes H.B.K. submitted to different concentrations of 2,4-D and BA.

Deus et al. (2007) induced calluses in seeds of Eucalyptus urophylla S.T. Blake by using alphanaphthaleneacetic acid (NAA) combined with TDZ. It was found that $0.5 \mathrm{mg} . \mathrm{L}^{-1} \mathrm{TDZ}$ was unable to induce calluses, but its combination with $0.1 \mathrm{mg} . \mathrm{L}^{-1}$ NAA resulted in callus induction in $100 \%$ of the explants.

Costa et al. (2008) tested different auxins (NAA, IBA, IAA, and 2,4-D) at the concentrations of 0, 2.5 , and $5.0 \mathrm{mg} . \mathrm{L}^{-1}$ in leaf and internodal explants of Piper hispidinervum C. DC. 2,4-D caused the highest levels of cellular death. On the other hand, Werner et al. (2009) achieved friable callus in leaf explants of Caesalpinia echinata Lam. at concentrations from 5.0 to $20.0 \mathrm{mg} . \mathrm{L}^{-1}$ 2,4-D, which were considered phytotoxic in the study of Costa et al. (2008). Correia (2010) induced callus in shoot tips of Bactris gasipaes Kunth. by combining $10.0 \mathrm{mg} . \mathrm{L}^{-1}$ 2,4-D with $3.0 \mathrm{mg} . \mathrm{L}^{-1}$ BA. The growth regulators 2,4-D and TDZ used in this study were effective for callus induction in fragments of immature seeds of $B$. excelsa. The obtained percentages were satisfatory and the induced callus will be used to continue the process of in vitro culture aiming to regenerate plantlets from these calluses. 


\section{CONCLUSION}

The highest callus induction levels in immature seeds of $B$. excelsa can be achieved by supplementing WPM culture medium with a combination of $2.0 \mathrm{mg} . \mathrm{L}^{-1} 2,4-\mathrm{D}$ and $3.2 \mathrm{mg} \cdot \mathrm{L}^{-1}$ TDZ in MS medium.

\section{REFERENCES}

BARBOSA, F.B.C. A Biotecnologia e a conservação da biodiversidade amazônica, sua inserção na política ambiental. C. C.\& T., v. 18, n. 2, p. 69-94, 2001.

BONNEAU, L.; BERANGER-NOVAT, N.; MONIN, J. Somatic embryogenesis and plant regeneration in a woody species: European Spindle Tree (Euonymus europaeus L.). Plant Cell Reports, n. 13, v. 3-4, p. 135-138, 1994.

BORGES, N.S.S.; BENBADIS, A.K.; MARCO, C.A.; SOMBRA, J.N.S. Avaliação da descontaminação, germinação e respostas morfogenéticas do mamão cultivado in vitro (Carica papaya L.). Revista Ciência Agronômica, v. 37, n. 2, p. 308-313, 2006.

CLEMENT, C.R. Castanha-do-Pará. In: CLAY, J.W.; SAMPAIO, P.T.B.; CLEMENT, C.R., editors. Biodiversidade amazônica - exemplos e estratégias de utilização. 1st ed. Manaus: INPA; 1999.

CORREIA, A.O. Calogênese em ápices caulinares de Bactris gasipaes H.B.K. [MScThesis]. Porto Velho: UNIR; 2010.

COSTA, F.H.S.; LOUREIRO, T.S.; PEREIRA, J.E.S. Influência de auxinas e tipos de explantes na indução de calos friáveis em Piper hispidinervum C. DC. Revista Ciência Agronômica, v. 39, n. 2, p. 269-274,2008

CYMERYS, M.; WADT, L.; KAINER, K.; ARGOLO, V. Castanheira - Bertholletia excelsa H.\&B. In: SHANLEY, P.; MEDINA, G.,editors. Frutíferas e Plantas Úteis na Vida Amazônica. Belém: CIFOR, Imazon; 2005. p. 61-73.

DEUS, D.A.; SOUZA, K.C.A.; DUARTE, M.S.; PEREIRA, R.P.W.; MONTEIRO, M.B.O.; ABREU, H.S. Calogênese em EucalyptusurophyllaS.T. Blake em diferentes concentrações de reguladores de crescimento. Revista Brasileira de Biociências, v. 5, n. 2, p. 717$719,2007$.

FERREIRA, E.A.; PASQUAL, M.; REZENDE, J.C. Calogênese em plântulas de figueira. Revista Ceres, v. 54, n. 312, p.112-117, 2007.
FERREIRA, E.A. Micropropagação, calogênese e irradiação da figueira 'roxo de valinhos'. [PhD Thesis]. Lavras: UFLA; 2006.

FILLION, M. Risques et benefices de l'alimentation locale dês communautés riveraines en Amazonie Brésilienne: lês effets du mercure, du plomb, Du sélénium et des acides gras oméga-3 sur dês fonctions visueles $[\mathrm{PhD}$ Thesis]. Montréal, Canada: Universitédu Québec à Montréal; 2011.

GRATTAPAGLIA, D.; MACHADO, M.A. Micropropagação. In: TORRES, A.L.; CALDAS, L.S.; BUSO, J.A., editors. Cultura de tecidos e transformação genética de plantas. Brasília: Embrapa-SPI/Embrapa-CNPH; 1998. p. 183-260.

GUERRA, M.P.; TORRES, A.C.; TEIXEIRA, J.B. Embriogênese somática e sementes sintéticas. In: TORRES, A.C.; CALDAS, L.S.; BUSO, J.A.,editors. Cultura de tecidos e transformação genética de plantas. Brasília: Embrapa-SPI/Embrapa-CNPH; 1998. p. 533-568.

KAINER, K.A.; DURYEA, M.L.; MALAVASI, M.M.; SILVA, E.R.; HARRISON, J. Moist storage of Brazil nut seeds for improved germination and nursery management. Forest Ecology and Management., v. 116, n. 1-3, p. 207-217, 1999.

KERBAUY, G.B. Fisiologia Vegetal. São Paulo: Guanabara-Koogan; 2004.

KHAN, P.S.S.V.; PRAKASH,E.; RAO, K.R. Callus induction and plant regeneration in Bixa orellana L., an annatto-yielding tree. In Vitro Cell. Developmental Biology - Plant, v. 38, p. 186-190, 2002.

LLOYD, G.; MCCOWN, B. Commercially feasible micropropagation of montain laurel, Kalmia latifolia, by use of shoot tip culture. Combined Proceedings, International Plant Propagators Society., n. 30, p. 421-327, 1981

LOCATELLI, M.; SOUZA, V.F. Castanha-do-Brasil: características agronômicas, produção de mudas e propagação vegetativa. Porto Velho: UEPAE; 1990.

MACHADO, M. P.; SILVA, A.L.L.; BIASI, L.A. Effect of plant growth regulators on in vitro regeneration of Lavandula dentata L. shoot tips. Journal of Biotechnology and Biodiversity, v. 2, n. 3, p. 28-31, 2011.

MÜLLER, C.H.; FREIRE, F.C.O. Influência de fungicidas na conservação e na germinação de amêndoas de castanha-do-brasil. Belém: EmbrapaCPATU; 1979. 
NOGUEIRA, R.C.; PAIVA, R.; OLIVEIRA, L.M.; SOARES, G.A.; SOARES, F.P.; CASTRO, A.H.F.;et al. Indução de calos em explantes foliares de muricipequeno (Byrsonima intermedia A. Juss.). Ciências e Agrotecnologia, v. 31, n. 2, p. 366-370,2007.

OLIVEIRA, A.L.; KIDO, E.A.; BENKO-ISEPPON, A.M.; KIDO, L.M.H. Efeito dos fitorreguladores BAP e 2,4-D sobre a indução de calos em Vigna unguiculata. Revista Brasileira de Biociências, v. 5, n. 2, p. 6971,2007 .

RIBEIRO， C.S.N.; SILVA， H.; SANTOS， J.W.; CARVALHO, J.M.F.C. Efeito do thidiazuron na micropropagação in vitro de dois genótipos de mamona via organogênese. Revista Brasileira Engenharia Agrícula Ambiental, v. 14, n. 4, p. 366-371, 2010.

SANTOS, M.R.A.; ROCHA, J.F.; FERREIRA, M.G.R.; CORREIA, A.O. Estabelecimento in vitro e calogênese em explantes foliares de pupunheira. Revista de Ciências Agrárias, v.55, n. 3, p.197-203, 2012.

SANTOS, M.R.A.; FERREIRA, M.G.R.; CORREIA, A.O.; REIS, N.F.C.; SANTOS, M.S. Indução de calos in vitro a partir de segmentos foliares de Coffea canephora cv. Conilon. Plant Cell Culture and Micropropagation., v. 6, n. 1, p. 26-32,2010.

SANTOS, M.R.A.; FERREIRA, M.G.R.; CORREIA, A.O.; ROCHA, J.F.; CORREA, K.C.S. Indução de calos em nervura mediana de folhas não expandidas de pupunheira (Bactris gasipaes Kunth.). Plant Cell Culture and Micropropagation., v. 6, n. 1, p. 33-39, 2010 .

SERRA, A.G.P.; PAIVA, R.; PAIVA, P.D.O. Análises bioquímicas de calos formados de explantes foliares de castanha-do-brasil (Bertholletia excelsa H.B.K.). Ciências Agrotecnológica., v. 24, n. 4, p. 833-840, 2000.

SHANLEY, P.; SERRA, M.; MEDINA, G. Frutíferas e plantas úteis na vida amazônica. 2nd ed. Belém: CIFOR, Embrapa Informação Tecnológica; 2010.

SILVA, A.S.; LUZ, J.M.Q.; RODRIGUES, T.M.; MARQUES, S.V.; MARQUES, R.V.; PASQUAL, M. Diferentes reguladores de crescimento na indução de calos e pró-embrióides em anteras de cafeeiro. Bioscience Journal, v. 25, n. 4, p. 19-27, 2009.

TANG, W.; OUYANG, F.; GUO, Z-C. Plant regeneration through organogenesis from callus induced from mature zygotic embryos of loblolly pine. Plant Cell Reports, v. 17, n. 6-7, p. 557-560, 1998.
THUROW, L.B.; BANDEIRA, J.M.; BRAGA, E.J.B.; PETERS, J.A.; BIANCHI, V.J. Desenvolvimento de um protocolo de regeneração in vitro de explantes foliares de ameixeira cv. 'America'. In: XVIII CIC, XI ENPOS \& I MC: Anais; 2009 Oct; Pelotas, Brazil. Pelotas: UFPel; 2009. p. 112-116.

WERNER, E.T.; CUZZUOL, G.R.F.; PESSOTTI, K.V.; LOPES, F.P.; ROGER, J.A. Controle da calogênese do pau-brasil in vitro. Revista Árvore, v. 33 , n. 6, p. 987-996,2009.
Recebido: 02/07/2013

Received: 07/02/2013

Aprovado: 03/09/2013 Approved: 09/03/2013 